\title{
Microlunatus parietis sp. nov., isolated from an indoor wall
}

\author{
Correspondence \\ Peter Kämpfer \\ peter.kaempfer@umwelt.uni- \\ giessen.de
}

\author{
P. Kämpfer, ${ }^{1}$ J. Schäfer, ${ }^{1}$ N. Lodders ${ }^{1}$ and K. Martin ${ }^{2}$ \\ ${ }^{1}$ Institut für Angewandte Mikrobiologie, Justus-Liebig-Universität Giessen, D-35392 Giessen, \\ Germany \\ ${ }^{2}$ Leibniz-Institut für Naturstoff-Forschung und Infektionsbiologie e.V., Hans-Knöll-Institut, \\ D-07745 Jena, Germany
}

The genus Microlunatus, as proposed by Nakamura et al. (1995), currently contains five recognized species, Microlunatus phosphovorus (Nakamura et al., 1995), M. ginsengisoli (Cui et al., 2007), M. aurantiacus (Wang et al., 2008), M. panaciterrae (An et al., 2008) and M. soli (Kämpfer et al., 2010). All these species are characterized chemotaxonomically by the presence of LL-diaminopimelic acid (LL-Dpm) in the cell-wall peptidoglycan, by MK- $9\left(\mathrm{H}_{4}\right)$ as the predominant menaquinone and the predominance of anteiso- $\mathrm{C}_{15: 0}$, iso- $\mathrm{C}_{15: 0}$ and iso- $\mathrm{C}_{16: 0}$ as the major fatty acids.

Strain $12-\mathrm{Be}-011^{\mathrm{T}}$ was enriched and recovered from interior wall plaster colonized with moulds in a house in Berlin, Germany, using previously described procedures (Schäfer et al., 2010). The novel strain was maintained on M79 agar (www.dsmz.de) and preserved at $-80{ }^{\circ} \mathrm{C}$ by mixing well grown M79 broth cultures in a $1: 1$ ratio with glycerol preservation medium containing $\mathrm{K}_{2} \mathrm{HPO}_{4}(1.26 \%), \mathrm{KH}_{2} \mathrm{PO}_{4}$

\footnotetext{
Abbreviation: LL-Dpm, LL-diaminopimelic acid.
}

The GenBank/EMBL/DDBJ accession number for the $16 \mathrm{~S}$ rRNA gene sequence of strain $12-\mathrm{Be}-011^{\top}$ is FN556016.

A supplementary table detailing fatty acid contents for strain $12-\mathrm{Be}-$ $011^{\top}$ and related species and a supplementary figure showing the results of the polar lipid analysis are available with the online version of this paper.
$(0.36 \%), \quad \mathrm{MgSO}_{4} \cdot 7 \mathrm{H}_{2} \mathrm{O} \quad(0.01 \%), \quad \mathrm{C}_{6} \mathrm{H}_{5} \mathrm{Na}_{3} \mathrm{O}_{7} \cdot 2 \mathrm{H}_{2} \mathrm{O}$ $(0.09 \%),\left(\mathrm{NH}_{4}\right)_{2} \mathrm{SO}_{4}(0.18 \%)$ and glycerol $(8.8 \%)$. Stock cultures of the isolate in liquid M79 supplemented with $5 \%$ DMSO were also maintained in the vapour phase of liquid nitrogen.

Gram-staining behaviour and cell morphology were observed microscopically as described by Kämpfer \& Kroppenstedt (2004). Strain $12-\mathrm{Be}-011^{\mathrm{T}}$ formed beige pigmented colonies with a characteristic wrinkly and shiny surface. Cells were Gram-positive, non-motile irregular rods. In older cultures ( $>5$ days of growth), cells changed their shape to short rods and coccoid forms. DNA isolation was performed with a commercial DNA extraction kit (GenElute Plant Genomic DNA mini prep kit, Sigma) after disruption of cells by a $1 \mathrm{~min}$ bead-beating step with $1 \mathrm{~g} 0.1 \varnothing$ Zirconia beads. Multiple sequence alignment and analysis of the data were performed with the MEGA (molecular evolutionary genetics analysis) software package version 4 (Tamura et al., 2007) and the ARB software package (December 2007 version; Ludwig et al., 2004) and the corresponding SILVA SSURef 95 database (release July 2008; Pruesse et al., 2007). Phylogenetic trees were constructed with the neighbourjoining method (Fig. 1) and the maximum-likelihood method with fastDNAml (Olsen et al., 1994, results not 


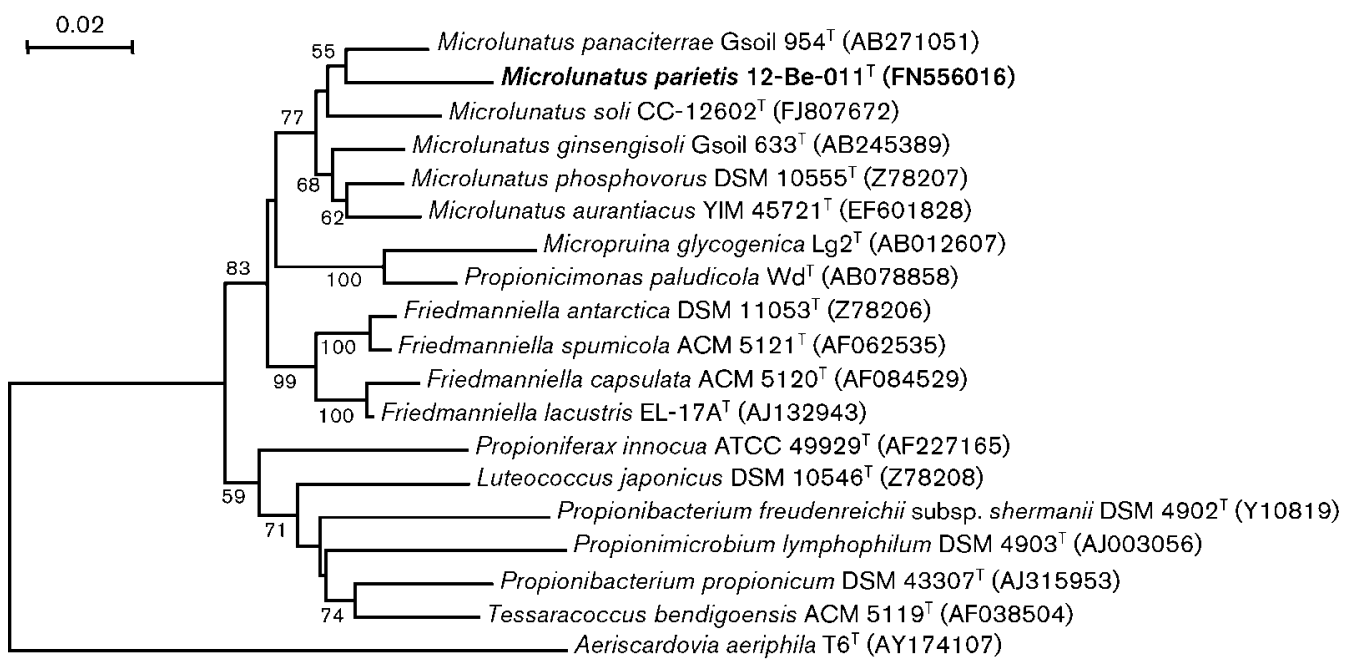

Fig. 1. Phylogenetic analysis based on 16S rRNA gene sequences available from the European Molecular Biology Laboratory database (accession numbers are given in parentheses). Multiple alignment, distance calculations (distance options according to the Kimura-2 model) and clustering with the neighbour-joining method were performed by using the MEGA software package (molecular evolutionary genetics analysis) version 4 (Tamura et al., 2007). Bootstrap values based on 1000 replications are listed as percentages at the branching points. Bar, 0.02 substitutions per nucleotide position.

shown). Bootstrap values were based on 1000 replications. The $16 \mathrm{~S}$ rRNA gene sequence of strain $12-\mathrm{Be}-011^{\mathrm{T}}$ was a continuous stretch of $1367 \mathrm{bp}$.

Sequence similarity calculations after pairwise local alignment showed that the closest relatives of strain $12-\mathrm{Be}-011^{\mathrm{T}}$ were M. panaciterrae Gsoil $954^{\mathrm{T}}(95.7 \%)$, M. aurantiacus YIM $45721^{\mathrm{T}}(95.5 \%)$, M. soli CC- $12602^{\mathrm{T}}(94.9 \%), M$. ginsengisoli Gsoil $633^{\mathrm{T}}(94.8 \%)$ and M. phosphovorus DSM $10555^{\mathrm{T}}(94.7 \%)$.

Bacterial biomass for chemotaxonomic investigations was prepared by cultivating strain $12-\mathrm{Be}-011^{\mathrm{T}}$ for $120 \mathrm{~h}$ in shake flasks in liquid organic medium M79 at 180 r.p.m. at $28{ }^{\circ} \mathrm{C}$. For fatty acid analyses, cells were grown on R2A agar (Oxoid) at $28{ }^{\circ} \mathrm{C}$ for 5 days.

Cell wall analysis was performed as described previously (Groth et al., 1996). The amino acids and peptides of cellwall hydrolysates were analysed by TLC on cellulose plates using the solvent systems as described by Schleifer \& Kandler (1972). The peptidoglycan hydrolysates contained LL-Dpm as the diagnostic diamino acid. The whole-cell sugars, determined by TLC (Becker et al., 1965), were arabinose, galactose, rhamnose and glucose.

Menaquinones were extracted as described by Collins et al. (1977) and analysed by HPLC (Groth et al., 1996). In common with all other species of the genus Microlunatus, strain $12-\mathrm{Be}-011^{\mathrm{T}}$ exhibited a quinone system with a high amount of $\mathrm{MK}-9\left(\mathrm{H}_{4}\right)(58 \%)$, followed by $\mathrm{MK}-8\left(\mathrm{H}_{2}\right)$ (28\%). Minor amounts of MK-8 (10\%) and MK-9 (3\%) were also detected. The absence of mycolic acids was shown by TLC as described by Minnikin et al. (1975). Polar lipids were extracted and identified by TLC as described by Minnikin et al. (1979). The major lipids were diphosphatidylglycerol, phosphatidylglycerol, phosphatidylinositol, two unknown phospholipids and one unknown glycolipid (see Supplementary Fig. S1 in IJSEM Online). The same complex pattern of phospholipids with the major components and some unknown glyco- and phospholipids has also been described for other species of the genus Microlunatus (Kämpfer et al., 2010).

Fatty acid analysis was performed according to Kämpfer \& Kroppenstedt (1996), except that strains were cultivated on R2A agar for 5 days at $28{ }^{\circ} \mathrm{C}$ prior to analysis.

The fatty acid profile of strain $12-\mathrm{Be}-011^{\mathrm{T}}$ was similar to those of the other closely related species $M$. phosphovorus, $M$. ginsengisoli and $M$. panaciterrae with predominant amounts of iso- $\mathrm{C}_{15: 0}$ (between 17 and $46 \%$ ) and anteiso$\mathrm{C}_{15: 0}$ (between $32 \%$ and $53 \%$ ), but minor differences (no traces of saturated and unsaturated fatty acids) could also be observed (see Supplementary Table S1 in IJSEM Online). The results of the comparative physiological characterization are given in Table 1 and the species description, with methods as described previously (Kämpfer et al., 1991). DNA-DNA hybridization experiments were not performed between strain $12-\mathrm{Be}-011^{\mathrm{T}}$ and the type strains of the genus Microlunatus because of the low $16 \mathrm{~S}$ rRNA gene sequence similarities $(<97 \%)$ to all other species of this genus. The differences observed in the fatty acid profiles and in the results of the physiological tests between the type strains of species of the genus Microlunatus (Table 1 and Supplementary Table S1) clearly warrant the creation of a separate species. 
Table 1. Physiological characteristics of the type strains of the genus Microlunatus

Strains: $1,12-\mathrm{Be}-011^{\mathrm{T}} ; 2$, M. soli CC- $12602^{\mathrm{T}} ; 3$, M. aurantiacus DSM $18424^{\mathrm{T}} ; 4$, M. phosphovorus DSM 10555 $5^{\mathrm{T}}$; , M. ginsengisoli DSM 17942 ${ }^{\mathrm{T}}$; 6, M. panaciterrae Gsoil $954^{\mathrm{T}}$. Data for M. panaciterrae are from An et al. (2008); all other data are from this study. All strains were positive for utilization of: L-arabinose ${ }^{*}$ D-glucose ${ }^{*}$, D-mannose ${ }^{*}$, maltose, melibiose, L-rhamnose, D-ribose and D-sorbitol. All strains were negative for the utilization of: D-gluconate, adipate, itaconate, L-alanine, 3-hydroxybenzoate and phenylacetate. + , Positive; - , negative; $(+)$, weakly positive.

\begin{tabular}{|c|c|c|c|c|c|c|}
\hline Characteristic & 1 & 2 & 3 & 4 & 5 & 6 \\
\hline \multicolumn{7}{|l|}{ Assimilation of: } \\
\hline Acetate & - & + & $(+)^{*}$ & - & $(+)$ & - \\
\hline$N$-Acetyl-D-glucosamine & $(+)$ & + & + & + & + & - \\
\hline Adonitol & + & + & - & + & + & - \\
\hline p-Arbutin & - & + & - & + & + & - \\
\hline Cellobiose & + & + & + & + & + & - \\
\hline D-Fructose & + & + & + & + & + & - \\
\hline D-Galactose & + & + & $(+)^{*}$ & $+^{*}$ & $+^{*}$ & - \\
\hline L-Histidine & - & $(+)$ & - & - & $(+)$ & - \\
\hline i-Inositol & + & + & $+^{*}$ & + & + & - \\
\hline L-Malate & - & $(+)$ & $(+)^{*}$ & + & + & - \\
\hline Maltitol & + & + & + & + & + & - \\
\hline D-Mannitol & + & + & $+^{*}$ & + & + & - \\
\hline L-Proline & - & $(+)$ & - & - & $(+)$ & - \\
\hline Propionate & - & + & $-*$ & - & - & - \\
\hline Salicin & - & + & - & + & + & + \\
\hline L-Serine & - & $(+)$ & $-{ }^{\star}$ & - & - & - \\
\hline Sucrose & + & + & + & - & + & + \\
\hline Trehalose & + & + & + & + & + & - \\
\hline D-Xylose & + & + & $+^{*}$ & $+^{*}$ & $+^{*}$ & - \\
\hline
\end{tabular}

${ }^{*}$ Data are in agreement with those of An et al. (2008).

\section{Description of Microlunatus parietis sp. nov.}

Microlunatus parietis (pa.ri'e.tis. L. gen. n. parietis of the wall of a house).

Rod-shaped and coccoid cells, Gram-positive, oxidasepositive, showing an aerobic respiratory metabolism. Good growth occurs after 5 days incubation on R2A agar, tryptone soy agar, M79 agar and nutrient agar at 25$30{ }^{\circ} \mathrm{C}$. The peptidoglycan type is A3 $\gamma$ based on LL-2,6diaminopimelic acid. The quinone system comprises menaquinones MK-9 $\left(\mathrm{H}_{4}\right)(58 \%)$, MK-8 $\left(\mathrm{H}_{2}\right)(28 \%)$ and minor amounts of MK-8 (10\%) and MK-9 (3\%). The polar lipid profile consists of diphosphatidylglycerol, phosphatidylglycerol, phosphatidylinositol, two unknown phospholipids and one unknown glycolipid. Major fatty acids are iso- $\mathrm{C}_{15: 0}$, anteiso- $\mathrm{C}_{15: 0}$ and, iso- $\mathrm{C}_{16: 0}$ (see Supplementary Table S1 in IJSEM Online). Many carbon sources are utilized, including $N$-acetyl-D-glucosamine, Larabinose, cellobiose, D-fructose, D-galactose, D-glucose, D-mannose, maltose, melibiose, L-rhamnose, D-ribose, sucrose, trehalose, D-xylose, adonitol, i-inositol, maltitol, D-mannitol and D-sorbitol. p-Arbutin, D-gluconate, acetate, adipate, cis-aconitate, citrate, propionate, L-malate, mesaconate, L-alanine, L-histidine, L-proline, L-serine, 3-hydroxybenzoate and phenylacetate are not utilized (Table 1).
The type strain, $12-\mathrm{Be}-011^{\mathrm{T}}\left(=\mathrm{DSM} 22083^{\mathrm{T}}=\mathrm{CCM} 7636^{\mathrm{T}}\right)$, was isolated by C. Trautmann from an indoor wall in Berlin, Germany.

\section{Acknowledgements}

We are grateful to Gundula Will and Carmen Schult for excellent technical assistance.

\section{References}

An, D.-S., Im, W.-T. \& Yoon, M.-H. (2008). Microlunatus panaciterrae sp. nov., a $\beta$-glucosidase-producing bacterium, isolated from soil in a ginseng field. Int J Syst Evol Microbiol 58, 2734-2738.

Becker, B., Lechevalier, M. P. \& Lechevalier, H. A. (1965). Chemical composition of cell-wall preparations from strains of various formgenera of aerobic actinomycetes. Appl Microbiol 13, 236-243.

Collins, M. D., Pirouz, T., Goodfellow, M. \& Minnikin, D. E. (1977). Distribution of menaquinones in actinomycetes and corynebacteria. J Gen Microbiol 100, 221-230.

Cui, Y. S., Im, W. T., Yin, C. R., Yang, D. C. \& Lee, S. T. (2007) Microlunatus ginsengisoli sp. nov., isolated from soil of a ginseng field. Int J Syst Evol Microbiol 57, 713-716.

Groth, I., Schumann, P., Weiss, N., Martin, K. \& Rainey, F. A. (1996). Agrococcus jenensis gen. nov., sp. nov., a new genus of actinomycetes with diaminobutyric acid in the cell wall. Int J Syst Bacteriol 46, 234-239. 
Kämpfer, P. \& Kroppenstedt, R. M. (1996). Numerical analysis of fatty acid patterns of coryneform bacteria and related taxa. Can $J$ Microbiol 42, 989-1005.

Kämpfer, P. \& Kroppenstedt, R. M. (2004). Pseudonocardia benzenivorans sp. nov. Int J Syst Evol Microbiol 54, 749-751.

Kämpfer, P., Steiof, M. \& Dott, W. (1991). Microbiological characterization of a fuel-oil contaminated site including numerical identification of heterotrophic water and soil bacteria. Microb Ecol 21, 227-251.

Kämpfer, P., Young, C.-C., Busse, H.-J., Chu, J.-N., Schumann, P., Arun, A. B., Shen, F.-T. \& Rekha, P. D. (2010). Microlunatus soli, isolated from soil. Int J Syst Evol Microbiol 60, 824-827.

Ludwig, W., Strunk, O., Westram, R., Richter, L., Meier, H., Kumar, Y., Buchner, A., Lai, T., Steppi, S. \& other authors (2004). ARB: A software environment for sequence data. Nucleic Acids Res 32, 13631371.

Minnikin, D. E., Alshamaony, L. \& Goodfellow, M. (1975). Differentiation of Mycobacterium, Nocardia, and related taxa by thin-layer chromatographic analysis of whole organism methanolysates. J Gen Microbiol 88, 200-204.

Minnikin, D. E., Collins, M. D. \& Goodfellow, M. (1979). Fatty acid and polar lipid composition in the classification of Cellulomonas, Oerskovia and related taxa. J Appl Bacteriol 47, 87-95.
Nakamura, K., Hiraishi, A., Yoshimi, Y., Kawaharasaki, M., Masuda, K. \& Kamagata, Y. (1995). Microlunatus phosphovorus gen. nov., sp. nov, a new gram-positive polyphosphate-accumulating bacterium isolated from activated sludge. Int J Syst Bacteriol 45, 17-22.

Olsen, G. J., Matsuda, H., Hagstrom, R. \& Overbeek, R. (1994). fastDNAml: a tool for construction of phylogenetic trees of DNA sequences using maximum likelihood. Comput Appl Biosci 10, 41-48.

Pruesse, E., Quast, C., Knittel, K., Fuchs, B. M., Ludwig, W., Peplies, J. \& Glöckner, F. O. (2007). sILVA: a comprehensive online resource for quality checked and aligned ribosomal RNA sequence data compatible with ARB. Nucleic Acids Res 35, 7188-7196.

Schäfer, J., Martin, K. \& Kämpfer, P. (2010). Prauserella muralis sp. nov., from an indoor environment. Int J Syst Evol Microbiol 60, 287290.

Schleifer, K. H. \& Kandler, O. (1972). Peptidoglycan types of bacterial cell walls and their taxonomic implications. Bacteriol Rev 36, 407-477.

Tamura, K., Dudley, J., Nei, M. \& Kumar, S. (2007). MEGA4: Molecular evolutionary genetics analysis (MEGA) software version 4.0. Mol Biol Evol 24, 1596-1599.

Wang, Y.-X., Cai, M., Zhi, X.-Y., Zhang, Y.-Q., Tang, S.-K., Yu, L.-H., Cui, X.-L. \& Li, W.-J. (2008). Microlunatus aurantiacus sp. nov., a novel actinobacterium isolated from a rhizosphere soil sample. Int J Syst Evol Microbiol 58, 1873-1877. 